\title{
Comparative Performance of Synthesised Silica Nanoparticles for Enhanced Hydrophilic Properties on Cotton
}

\section{Primerjalna zmogljivost sintetiziranih nanodelcev silicijevega dioksida za izboljšanje hidrofilnosti bombaža}

\author{
Original Scientific Article/lzvirni znanstveni članek
}

Received/Prispelo 4-2019. Accepted/Sprejeto 10-2019

\begin{abstract}
Chemicals in nano-form are free from aggregates and low concentration effective. The nanoparticles of certain chemicals have been found to be of substantial importance for application in textiles as well as allied fields. Nano-silica is one of such nanoparticles possessing enormous potential for multi-functional application on cotton. However, the cost of nanoparticles is remarkably high, thus limiting their commercial applications. This study discusses the manufacture of silica nanoparticles in a laboratory, their characterisation, succeeded by their application on cotton. The performance was compared with those obtained with tailormade silica nanoparticles from manufacturers. It was found that laboratory-made silica nanoparticles are relatively capable of developing a parallel finishing effect on cotton compared to those obtained with tailormade silica nanoparticles.

Keywords: tetraethyl orthosilicate, nano-silica, absorbency, tensile strength

\section{Izvleček}

Snovi v nanoobliki ne vsebujejo agregatov in so učinkovite pri nizki koncentraciji. Ugotovljeno je bilo, da so nanodelci nekaterih snovi pomembni za uporabo v tekstilstvu in na sorodnih področjih. To velja za nanodelce silicijevega dioksida, ki imajo velike možnosti za oblikovanje večfunkcionalnih lastnosti na bombažu. Vendar pa izjemno visoka cena nanodelcev omejuje njihovo tržno uporabo. Ta študija obravnava laboratorijsko izdelavo nanodelcev silicijevega dioksida in njihovo karakterizacijo, ki ji je sledila uspešna uporaba na bombažu. Njihova učinkovitost je bila primerjana s tržnimi produkti nanodelcev silicijevega dioksida. Ugotovljeno je bilo, da so bili laboratorijsko izdelani nanodelci silicijevega dioksida sposobni na bombažu oblikovati primerljive plemenitilne učinke kot tržno dostopni silicijevi nanodelci. Ključne besede: tetraetil ortosilikat, nanosilica, vpojnost, natezna trdnost
\end{abstract}

\section{Introduction}

Applied technology has witnessed remarkable progress due to the inclusion of nanotechnology. By minimizing the cluster size of particles, gigantic changes have been observed in the properties exhibited by the particles due to the quantum effect shown by nanoparticles [1]. These enhanced

Corresponding author/Korespondenčni avtor:

J N Chakraborty

E-mail:chakrabortyjn@gmail.com properties may be inherited on a fabric substrate by applying nano chemicals to a fabric. Different functional properties are induced in the fabric using nanoparticles such as water/oil repellence, self-cleaning properties, UV blocking and antimicrobial properties [2-6]. In some cases, nanoparticles are also observed to enhance colour fastness [7].

Tekstilec, 2019, 62(4), 278-287

DOI: 10.14502/Tekstilec2019.62.278-287 
Out of several types of nanoparticles possessing technological importance, i.e. $\mathrm{TiO}_{2}, \mathrm{ZnO}$ and $\mathrm{SiO}_{2}$, the latter, i.e. $\mathrm{SiO}_{2}$ has been found to be rather interesting. Acrylicbased polyurethane nano-particulate clearcoats are reinforced with fumed and precipitated nano-silica reinforcements to induce scratch proofing as well as improved abrasion resistance [8].

Mini-emulsified butylacrylate/acrylonitrile (BA/AN) copolymer-silica nanoparticles nanocomposites containing three different concentrations of silica nanoparticles, i.e. 1, 3 and 5 (wt\%), were applied as a functional binder via silk screen printing on $100 \%$ cotton and $100 \%$ polyester. The prepared copolymer, silica nanoparticles and their nanocomposites were characterised. The evaluation of surface morphology, colourfastness, hydrophobic behaviour and UV protection of printed fabrics showed an improvement in colour fastness, UV protection and self-cleaning properties against only $1 \%$ silica nanoparticles. Moreover, almost all silica nanoparticles remained strongly adhered to the binder that provides long activity for printed fabrics with no harmful effects for users [9].

Imparting a water repellent treatment on a cotton fabric by sequentially coating the cotton fabric with a polymer nanocomposite comprising a C-6 perfluorinated acrylic copolymer and silica nanoparticles and polydimethylsiloxane (PDMS) resin resulted in repelling water droplets at the roll-off angles well below $20^{\circ}$, even impinging small droplets $(8 \mathrm{~mL})$ could be repelled with the droplet roll-off angle of $17^{\circ}$. The treated fabrics were able to hold a hydrostatic head pressure of $2.56 \mathrm{kPa}$ before leak. The finished cotton fabric resisted wear abrasion under $17.5 \mathrm{kPa}$ up to 30 abrasion cycles. Furthermore, the open porous structured was preserved allowing breathability. The application of low-cost polymers and non-toxic ingredients in this finish opens scope for commercial application [10].

Silver nanoparticles with the average size of $14 \mathrm{~nm}$ were immobilised on silica nanoparticles surfaces with the average particle size of $150 \mathrm{~nm}$ derived from rice husk, dispersed in binder and coated on a textile surface. The mass ratio of silica nanoparticles was varied. The UV protection factor (UPF) of treated textiles was substantially enhanced by more than 6 and 7 folds compared to the textile binder treated and control textile, respectively. The antibacterial properties faced a drastic increase as well. The textile coated with silver nanoparticles immobilised over silica nanoparticles achieved an increase in the clear inhibition zone compared to the textile containing only silver nanoparticles, where only a $30 \mathrm{~mm}$ clear zone was recorded [11]. In addition, an excellent hydrophobic surface was obtained at the water contact angle of $145^{\circ}$.

In fields other than textile, silica nanoparticles are extensively used in the manufacturing of durable superamphiphobic nano-silica and epoxy composites [12], surface treatments [13], coating and film formation [14-17], cement technology [18, 19], drilling fluid in natural gas extraction [20], multifunctional effects on wooden materials [21], in the field of medicines [22], immobilisation of protein [23], separation of components from emulsion [24], constructing pig houses [25] and many others. However, very high costs of silica nanoparticles restrict their use in commercial application.

Although the application of silica nanoparticles was studied on textile fabrics to develop numerous functional properties, e.g. improvement in colour fastness, UV protection, self-cleaning, water repellent breathable fabrics, anti-bacterial and hydrophobic fabrics etc, no such study has yet been carried out to enhance the water absorption of treated cotton fabrics.

In this work, a pre-treated cotton fabric was finished with three types of $\mathrm{SiO}_{2}$, i.e. normal bulk, laboratory synthesised and tailor-made, to see their comparative performance in the hydrophilic silica finish on cotton. Organometallic hydrolysis followed by condensation reaction was used for the sol gel synthesis of nanoparticles. Synthesised nanoparticles were characterised for particle size, chemical and physical characteristics, and colour. The finished cotton fabric was evaluated for absorbency, cyclic wash fastness, tensile strength, pore size and stiffness.

\section{Materials and methods}

\subsection{Materials}

A plain, woven, pre-treated cotton fabric, possessing 55.0 ends/cm, 28.3 picks/cm, with 14.76 tex of the linear density of warp yarn, 14.76 tex of the linear density of weft yarn and $126 \mathrm{~g} / \mathrm{m}^{2}$ of mass per unit area was used in this study.

The precursor tetraethyl orthosilicate (TEOS, $\mathrm{SiC}_{8} \mathrm{H}_{20} \mathrm{O}_{4}$, AR) was procured from $\mathrm{M} / \mathrm{s}$ Sigma Aldrich. Propan-2-ol (Isopropyl alcohol, $\mathrm{C}_{3} \mathrm{H}_{8} \mathrm{O}$, AR), ammonium hydroxide $\left(\mathrm{NH}_{4} \mathrm{OH}, 25 \% \mathrm{v} / \mathrm{v}\right)$, ammonium fluoride $\left(\mathrm{NH}_{4} \mathrm{~F}, \mathrm{AR}\right)$ and acrylic acid 
binder $\left(\mathrm{C}_{3} \mathrm{H}_{4} \mathrm{O}_{2}\right.$, AR) were procured from $\mathrm{M} / \mathrm{s}$ SDFCL, Mumbai and distilled water was used for synthesis. Glass apparatus was boiled in a nitric acid solution prior to use.

\subsection{Methods}

$\mathrm{SiO}_{2}$ nanoparticles were synthesised in a laboratory after the optimisation in the experimental setup as shown in Figure 1.

Different combinations of the recipe for the $\mathrm{SiO}_{2}$ nanoparticle synthesis were tested for the smallest nanoparticle obtained. A further optimised recipe was used for the synthesis and application on the fabric. The complete process was conducted at room temperature.

For the synthesis of $\mathrm{SiO}_{2}$ nanoparticles, 0.01 mole $(2.08 \mathrm{~g})$ of TEOS was dissolved in $60 \mathrm{~mL}$ of propanol and this solution was labelled as solution A. 0.02 mole $(0.36 \mathrm{~g})$ of water and 0.04 mole $(1.40 \mathrm{~g})$ of ammonia solution was dissolved in $60 \mathrm{~mL}$ propanol and was labelled as solution B. Solution C was prepared by dissolving $1.852 \mathrm{~g}$ of ammonium fluoride in $20.50 \mathrm{~g}$ of ammonium hydroxide (30\%), and then dissolving this solution in $100 \mathrm{~mL}$ of distilled water.

Solution A was transferred to a flat bottom flask and vigorously stirred using a magnetic stirrer. Solution $\mathrm{B}$ was transferred to a burette and was added to solution A over 80 min of uniformly drop by drop pouring with constant stirring. The drop of water had to be from the height closest to the fabric, yet not touching it, otherwise the fabric might absorb more water. After solution B was emptied completely into solution $\mathrm{A}$, the flat bottom flask was covered and the stirring continued for another $60 \mathrm{~min}$ to get a colourless clear solution. This solution was nano sol.

At the end of stirring, 5-6 drops of solution C were added to nano sol and this solution was then shifted to a beaker. Within a few seconds, the final solution transformed into a slightly bluish white gel. This gel was heated up to evaporate the solvent and obtain bulky, flower shaped and very light powdery $\mathrm{SiO}_{2}$ nanoparticles.

\subsection{Characterisation}

The nanoparticles were characterised for their size, chemical and physical characteristics using the ultraviolet visible (UV-VIS) spectroscopy (Lambda 365, Perkin Elmer), particle size analysis (Beckman Coulter, US ), and primary salt analysis techniques, e.g. colours of both, nano sol formed and nanoparticles obtained, colour change upon heating, visual appearance and texture of nanoparticles.

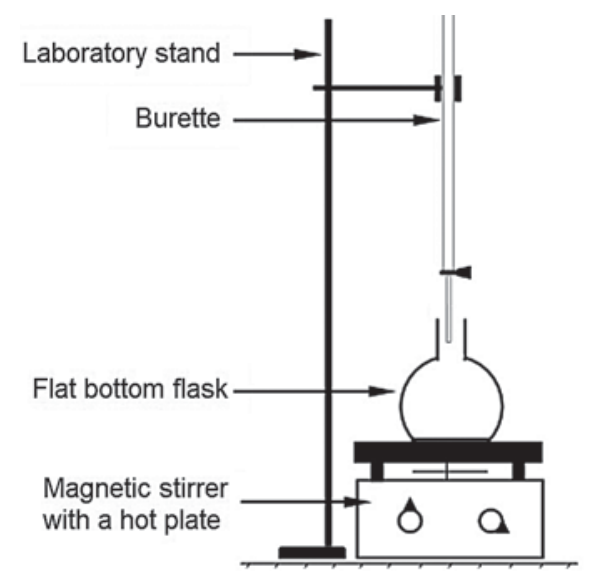

Figure 1: Schematic of experimental setup for synthesis of $\mathrm{SiO}_{2}$

\subsection{Process optimisation}

To synthesise smallest nanoparticles, the Box and Behnken design of experiment was used. The variable parameters were the amount of solvent (propanol), molar ratio of water and ammonia solution with respect to TEOS for catalyst solution, and time of adding catalyst solution to precursor solution. Different combinations of recipes were used to obtain nanoparticles. The nanoparticles obtained from design combinations were analysed with UV-VIS spectroscopy at constant weight by volume solution of nanoparticles and water.

For different particle sizes and identical concentration of the nanoparticle solution, the absorption value of a characteristic peak of the chemical under observation varied according to its size. The larger the size of particles, the lower is the absorption value. This is due to the fact that as the surface area of particles decreases, the number of active sites decreases, which consequently decreases the absorption value. Thus, the nanoparticle solution with the highest absorption value has the smallest particle size. For the analysis of the Box and Behnken design, making surface plots and obtained results, the Statease Design-Expert 6 software was used.

\subsection{Coating of nanoparticles on fabric}

The pad-dry-cure method was followed for the application of nanoparticles to the fabric. $\mathrm{SiO}_{2}$ nanoparticles at varying concentrations, i.e. $0.5 \%, 1 \%$ and $1.5 \%$, were used to prepare pad liquor with 
$0.5 \%$ acrylic acid as binder. The fabric was padded with liquor in a padding mangle with $1 \mathrm{~kg} / \mathrm{cm}^{2}$ to achieve around $80 \%$ expression. The padded samples were dried at $80^{\circ} \mathrm{C}$ in a hot air oven and were cured at $150^{\circ} \mathrm{C}$ for $5 \mathrm{~min}$.

\subsection{Functional and wash fastness testing}

Absorbency time was taken as a parameter to evaluate the functional properties of silica nanoparticles applied to the fabric. A drop of water was allowed to fall onto a dry fabric surface and the time taken for the drop to completely disappear into the fabric was noted with the help of a stop watch.

The wash fastness of the finish was conducted in line with the International Standard Organisation Method 3 (ISO-3) specifications. The washing was done with a soap solution $(5 \mathrm{~g} / \mathrm{L})$, sodium carbonate $\left(\mathrm{Na}_{2} \mathrm{CO}_{3}, 2 \mathrm{~g} / \mathrm{L}\right)$, liquor ratio $(1: 50)$, temperature $(60 \pm 2){ }^{\circ} \mathrm{C}$ for $30 \mathrm{~min}$. The fabric underwent 5 wash cycles and the functional testing was carried out after each wash.

\subsection{Physical testing of fabric}

The tensile behaviour of the finished fabric was tested using the ASTM D5035 test method on a Universal testing machine (Zwick, Switzerland). The particle size analyser (Beckman Coulter, US) was used to measure the size of silica nanoparticles and the pore size measurement (ASTM 316) was done to evaluate the change in pore size of the fabric after applying the finish (Capillary Flow Porometer, CFP 1100AN, PMI, India). In this test, a wetting liquid is allowed to spontaneously fill the pores of the specimen $(2 \mathrm{~cm})$ and non-reacting pressurised gas is allowed to displace the liquid from the pores. The gas pressure and flow rates through the wet and dry samples are accurately measured. The gas pressure required to remove the liquid from the pores and cause gas to flow is given by the Washburn equation: $D=4 \gamma \cos \theta / p$, where $\mathrm{D}$ is pore diameter, $\gamma$ is surface tension of liquid, $\theta$ is contact angle of liquid, and $p$ is differential gas pressure. From the measured gas pressure and flow rate, the pore throat diameter, pore size distribution and gas permeability are calculated.

The ASTM D 1388 cantilever test method was used to determine fabric stiffness. In this test, the fabric specimen is allowed to bend under its own weight. The free length, which bends under its own weight sufficiently to make its leading edge intersect the line of $41.5^{\circ}$ inclinations, is called the bending length of the fabric. The dimension of the specimen used for the testing is $20 \mathrm{~cm} \times 5 \mathrm{~cm}$.

The ASTM D 1388 cantilever test method and stiffness tester (Unilab, India) were used to evaluate fabric stiffness. The sample size of $20 \mathrm{~cm} \times 5 \mathrm{~cm}$ was allowed to bend under its own weight to just intersect the $45^{\circ}$ line.

\section{Results and discussion}

\subsection{Characterisation of nanoparticles}

The characterisation of nanoparticles was performed using UV-VIS spectroscopy to confirm the $\mathrm{SiO}_{2}$ synthesis. A further particle size analysis (PSA) was done to confirm the formation of nanoparticles and analyse the size of synthesised particles. The characteristic peak of $\mathrm{SiO}_{2}$ was observed in the range $190-195 \mathrm{~nm}$. The absorption peak wavelength coincides with the $\mathrm{SiO}_{2}$ nanoparticles procured from M/s Sigma Aldrich.

The particle size analysis was conducted on a Beckman Coulter Delsa ${ }^{\mathrm{mt}}$ Nano. The particle diameter was $345.3 \mathrm{~nm}$. The intensity distribution curve is shown in Figure 2.

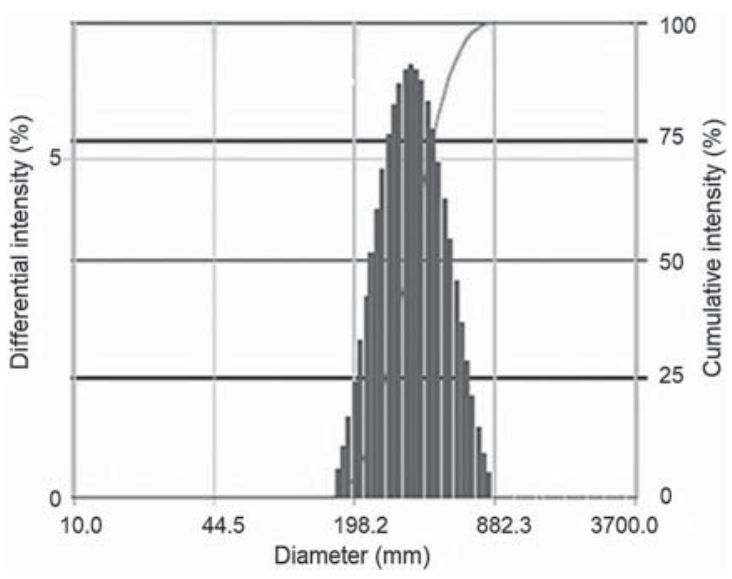

Figure 2: Intensity distribution of $\mathrm{SiO}_{2}$ nanoparticles

\subsection{Process optimisation of synthesis}

For the optimisation of synthesis, the Box and Behnken design of experiment was used. The amount of water and ammonia used in terms of parts per unit part of TEOS was 2 to 6 , propanol $60 \mathrm{~mL}$ to $80 \mathrm{~mL}$ and the time of introducing solution B into solution A (pouring time) was $30 \mathrm{~min}$ to $90 \mathrm{~min}$, these data being used as process parameters and end points for the design of the experiment. Different 
Table 1: Combinations of reaction parameters for synthesis of $\mathrm{SiO}_{2}$ nanoparticles

\begin{tabular}{|c|c|c|c|c|c|}
\hline S. no. & 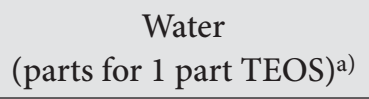 & $\begin{array}{c}\text { Ammonia } \\
\left.\text { (parts for } 1 \text { part TEOS) }{ }^{a}\right)\end{array}$ & $\begin{array}{l}\text { Propanol } \\
\text { (mL) }\end{array}$ & $\begin{array}{c}\text { Pouring } \\
\text { time (min) }\end{array}$ & Absorbance \\
\hline 1 & 2 & 4 & 60 & 30 & 0.25 \\
\hline 2 & 4 & 4 & 80 & 30 & 0.16 \\
\hline 3 & 6 & 2 & 60 & 60 & 0.13 \\
\hline 4 & 4 & 2 & 40 & 60 & 2.66 \\
\hline 5 & 4 & 4 & 60 & 60 & 2.59 \\
\hline 6 & 4 & 6 & 60 & 90 & 1.31 \\
\hline 7 & 4 & 2 & 80 & 60 & 0.06 \\
\hline 8 & 4 & 2 & 60 & 30 & 0.5 \\
\hline 9 & 4 & 6 & 40 & 60 & 2.51 \\
\hline 10 & 4 & 6 & 60 & 30 & 0.17 \\
\hline 11 & 6 & 4 & 80 & 60 & 1.74 \\
\hline 12 & 4 & 6 & 80 & 60 & 0.24 \\
\hline 13 & 4 & 4 & 60 & 60 & 2.59 \\
\hline 14 & 6 & 4 & 60 & 90 & 0.07 \\
\hline 15 & 6 & 6 & 60 & 60 & 2.78 \\
\hline 16 & 2 & 4 & 60 & 90 & 1.5 \\
\hline 17 & 2 & 6 & 60 & 60 & 1.79 \\
\hline 18 & 4 & 4 & 60 & 60 & 2.59 \\
\hline 19 & 6 & 4 & 40 & 60 & 1.33 \\
\hline 20 & 4 & 4 & 80 & 90 & 0.13 \\
\hline 21 & 4 & 4 & 60 & 60 & 2.59 \\
\hline 22 & 2 & 4 & 40 & 60 & 1.86 \\
\hline 23 & 4 & 2 & 60 & 90 & 1.35 \\
\hline 24 & 4 & 4 & 40 & 90 & 2.72 \\
\hline 25 & 4 & 4 & 40 & 30 & 2.98 \\
\hline 26 & 2 & 4 & 80 & 60 & 3.34 \\
\hline 27 & 2 & 2 & 60 & 60 & 2.53 \\
\hline 28 & 6 & 4 & 60 & 30 & 0.43 \\
\hline 29 & 4 & 4 & 60 & 60 & 2.59 \\
\hline
\end{tabular}

a) Part for 1 part in terms of weight

combinations of reaction parameters were used and their respective absorbance values are shown in Table 1.

The $\mathrm{R}^{2}$ value was found to be 0.6639 and the computed equation for absorption is:

Absorption $(\mathrm{AU})=-4.69+0.62 \times($ water $/$ parts for 1 part of TEOS $)+0.31 \times($ ammonia/parts for 1 part of TEOS $)+0.03($ propanol $/ \mathrm{mL})+0.18($ time $/ \mathrm{min})-0.10$ (water/parts for 1 part of TEOS) $)^{2}-0.16 \times$ (ammonial $^{2}$ parts for 1 part of TEOS $)^{2}-4.61 \times(\text { propanol } / \mathrm{ml})^{2}-$
$1.33 \times(\text { time } / \text { min })^{2}+0.21 \times[($ water/parts for 1 part of TEOS $) \times($ ammonia/parts for 1 part of TEOS)] $6.68 \times[($ water/parts for 1 part of TEOS $) \times($ propa$\mathrm{nol} / \mathrm{ml})]-6.70 \times[($ water/parts for 1 part of TEOS $) \times$ $($ time $/ \mathrm{min})]+2.06 \times[($ ammonia/parts for 1 part of TEOS $) \times($ propanol $/ \mathrm{mL})+1.20 \times[$ (ammonia/parts for 1 part of TEOS $) \times($ time $/ \mathrm{min})]+9.58 \times[($ propa $\mathrm{nol} / \mathrm{mL}) \times($ time $/ \mathrm{min})]$

The 0.6639 value of $R^{2}$ is relatively good, possessing $66 \%$ accuracy on the above equation. In general, $\mathrm{R}^{2}$ 
should approach 1 for best performance; however, in the case of the synthesis of a chemical, the value $\mathrm{R}^{2}$ remains substantially below 1 and more than $60 \%$ is considered satisfactory arising from the presence of impurities in chemicals.

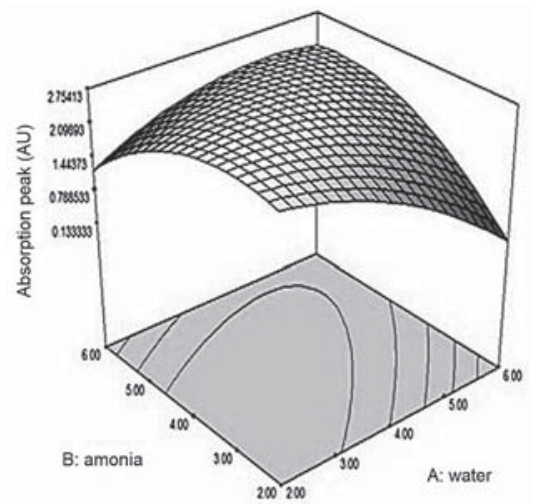

a)

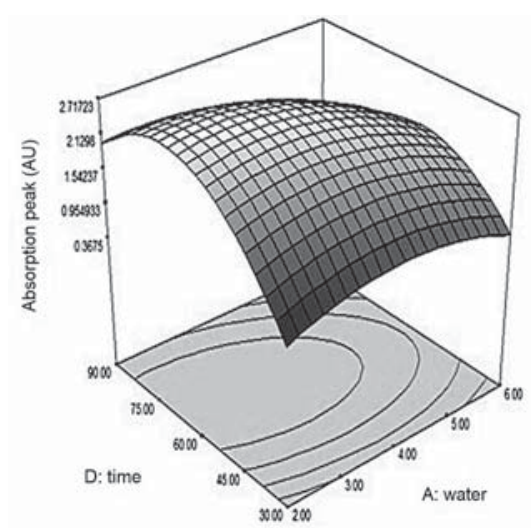

c)

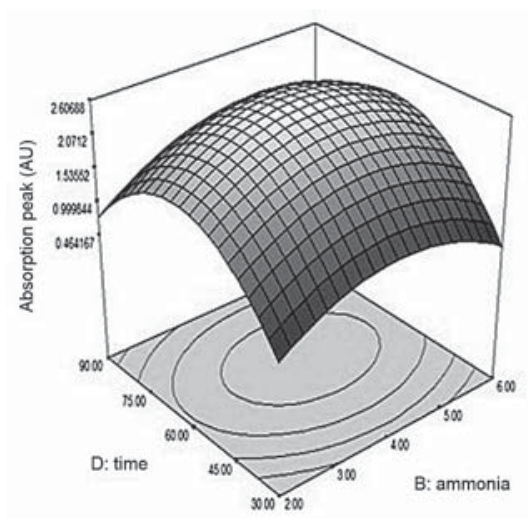

e)
Surface plots describing the effect of the combination of different parameters on absorbance for the experiment are shown in Figure 3. The optimised recipe used for the synthesis of $\mathrm{SiO}_{2}$ was the combination no. 16, i.e. water 2 parts, ammonia 4 parts,

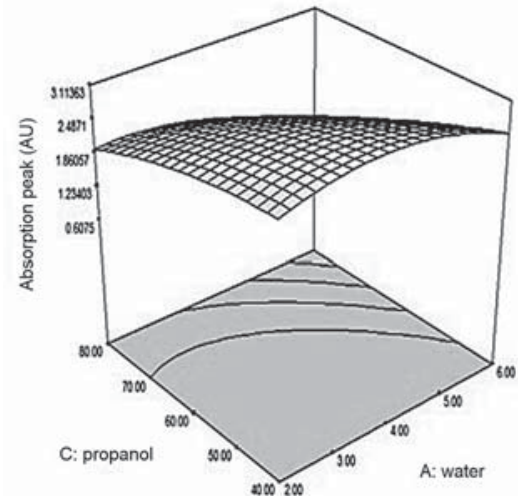

b)

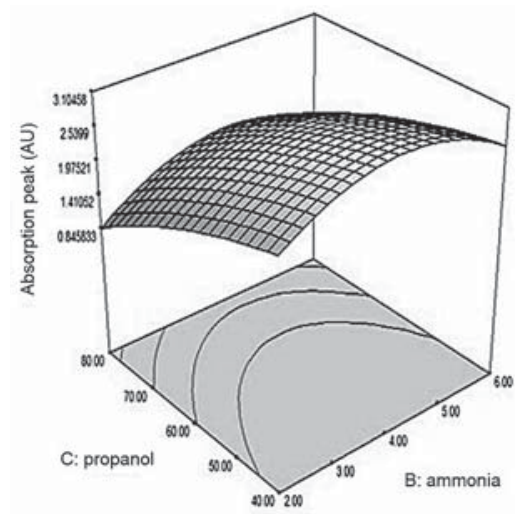

d)

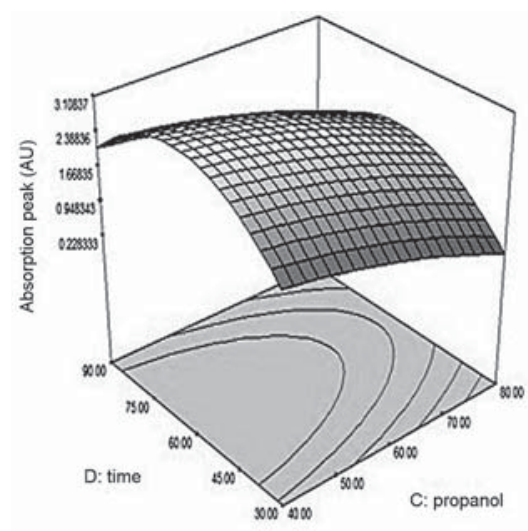

f)

Figure 3: Surface plots for change in absorbance against different combinations of: a) ammonia and water, b) propanol and water, c) pouring time and water, d) propanol and ammonia, e) pouring time and ammonia, f) pouring time and propanol 
propanol $60 \mathrm{~mL}$, pouring time $90 \mathrm{~min}$ and absorption 1.5 .

The interaction of water and ammonia has been depicted in the surface plot (Figure 3a), according to which, a higher amount of ammonia (in parts) as compared to water leads to a higher absorption peak, i.e. an increase in the share of ammonia in the reaction mixture helps increase the absorption.

While the interaction of propanol and water (cf. Figure $3 b$ ) suggests that the lower the concentration of water in propanol, the higher the absorption peak, achieving higher absorption values, the water concentration shall be lower in propanol. In Figures $3 \mathrm{c}$ and $3 \mathrm{f}$, it can be observed that prolonged pouring times of water in the reaction mixture give higher peak absorption values, and that the same trend is valid for propanol. Therefore, to achieve higher peak values, in general, the pouring time should be increased to an optimised limit. On the other hand, the too much increased time also increases the chances of possible coagulation of particles and decreased peak intensity. Whereas Figure 3e implies a decrease in the absorption peak when the pouring time and the amount of ammonia is below or above the optimised limit of 60 min of pouring and 4 parts of used ammonia, the pouring time and ammonia in the mixture has a specific ratio in which the highest absorption can be achieved. As observed in Figure $3 \mathrm{~d}$, lower amounts of propanol with respect to higher ammonia yields give a higher absorption peak value, but increased/decreased amount of ammonia than the optimised limit also leads to a decrease in the absorption peak.

A further relation of the absorption peak value and particle size can be interpreted as described in section 2.4. The higher the absorption peak values, the smaller the particle size.

\subsection{Scanning electron microscopy (SEM)}

SEM was conducted to study the surface morphology of the fabric surface after finishing and is shown in Figure 4.

It can be observed that the fibres retained a uniform layer of nanoparticles on them. A closer view (cf. Figure $4 c$ ) is indicative of a white ball shaped nanoparticle stuck on the fibre surface without any damage in the fibre structure. Finer cracks on the fibre (cf. Figure 4c) is a consequence of padding pressure during the application, developing a minor fibre damage, which is also too small to be noticeable at smaller resolutions.

\subsection{Functional testing}

The tests for absorbency were performed on an unfinished control, a sample finished with bulk $\mathrm{SiO}_{2}$, synthesised nano $\mathrm{SiO}_{2}$ and tailor-made nano $\mathrm{SiO}_{2}$ (procured from M/s Sigma Aldrich, particle size less than $99 \mathrm{~nm}$ ). The results of tests are shown in Table 2. The synthesised as well as tailor-made $\mathrm{SiO}_{2}$ nanoparticles increased the hydrophilicity and absorbency up to the identical extent after each wash while the absorbency values slightly decreased yet remained better in performance against the unfinished control. Despite bulk $\mathrm{SiO}_{2}$ showing some positive effects on absorbency, this went on decreasing remarkably and after 5 cycles, it became identical to the unfinished sample. This confirms that $0.50 \%$ of nanoparticles were adequate to improve absorbency, whereas an additional increase in the amount of nanoparticles could not further improve absorbency.

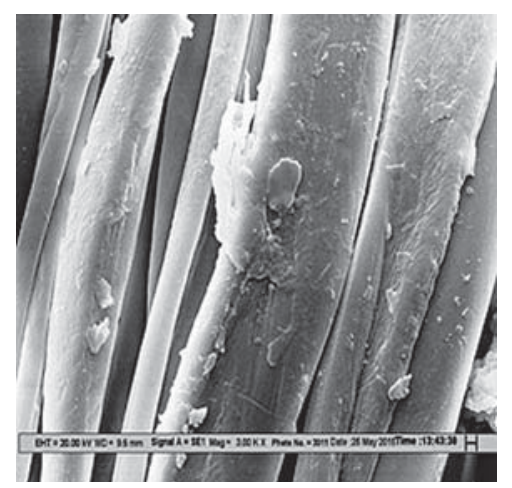

a)

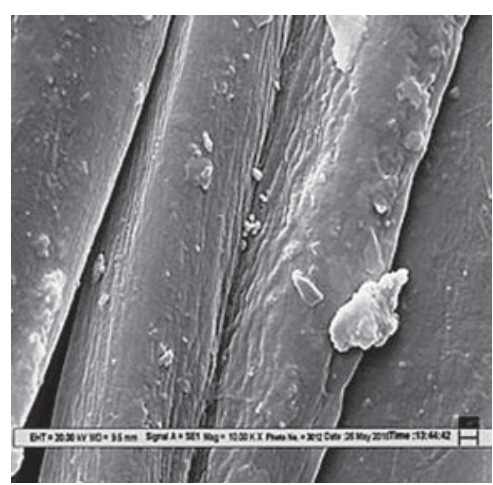

b)

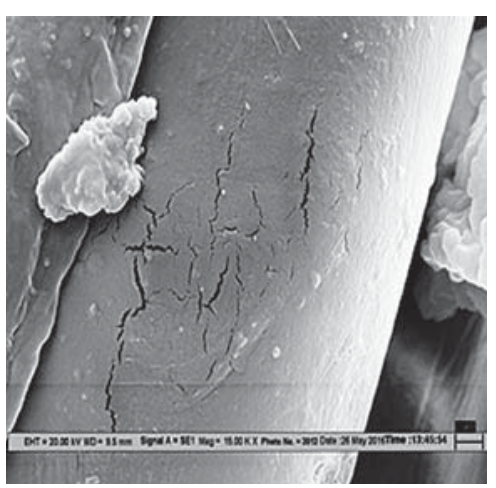

c)

Figure 4: SEM images of fabric sample surface after application of $\mathrm{SiO}_{2}$ nano finish: a) 3,000× magnification, b) 10,000 $\times$ magnification and c) 15,000× magnification 
Table 2: Comparative performance of finished fabrics against cyclic wash fastness testing

\begin{tabular}{|c|l|c|c|c|c|c|c|c|}
\hline \multirow{2}{*}{$\begin{array}{c}\text { Sample } \\
\text { no. }\end{array}$} & \multicolumn{2}{|c|}{ Sample description } & Wash 0 & Wash 1 & Wash 2 \\
{$[\mathrm{s}]$} & {$[\mathrm{s}]$} & $\begin{array}{c}\text { Wash 3 } \\
{[\mathrm{s}]}\end{array}$ & $\begin{array}{c}\text { Wash 4 } \\
{[\mathrm{s}]}\end{array}$ & $\begin{array}{c}\text { Wash 5 } \\
{[\mathrm{s}]}\end{array}$ \\
\hline 1 & Control sample & 0.00 & 2.5 & & & & & \\
\hline 2 & Bulk silica & 0.50 & $<1$ & 1 & 1.5 & 2 & 2.5 & 2.5 \\
\hline 3 & Bulk silica & 1.00 & $<1$ & 1 & 1.5 & 2 & 2.5 & 2.5 \\
\hline 4 & Bulk silica & 1.50 & $<1$ & 1 & 1.5 & 2 & 2.5 & 2.5 \\
\hline 5 & Tailor-made & 0.50 & b) & $<0.5$ & $<1$ & 1 & c) & d) \\
\hline 6 & Tailor-made & 1.00 & b) & $<0.5$ & $<1$ & 1 & c) & d) \\
\hline 7 & Tailor-made & 1.50 & b) & $<0.5$ & $<1$ & 1 & c) & d) \\
\hline 8 & Synthesised & 0.50 & b) & $<0.5$ & $<1$ & 1 & c) & d) \\
\hline 9 & Synthesised & 1.00 & b) & $<0.5$ & $<1$ & 1 & c) & d) \\
\hline 10 & Synthesised & 1.50 & b) & $<0.5$ & $<1$ & 1 & c) & d) \\
\hline
\end{tabular}

a) $\mathrm{SiO}_{2}$ nanoparticles concentrations, b) Instant, c) Little more than 1, d) Around 2

\subsection{Physical properties}

\subsubsection{Tensile strength}

The obtained tensile strength of different samples is shown in Figure 5.

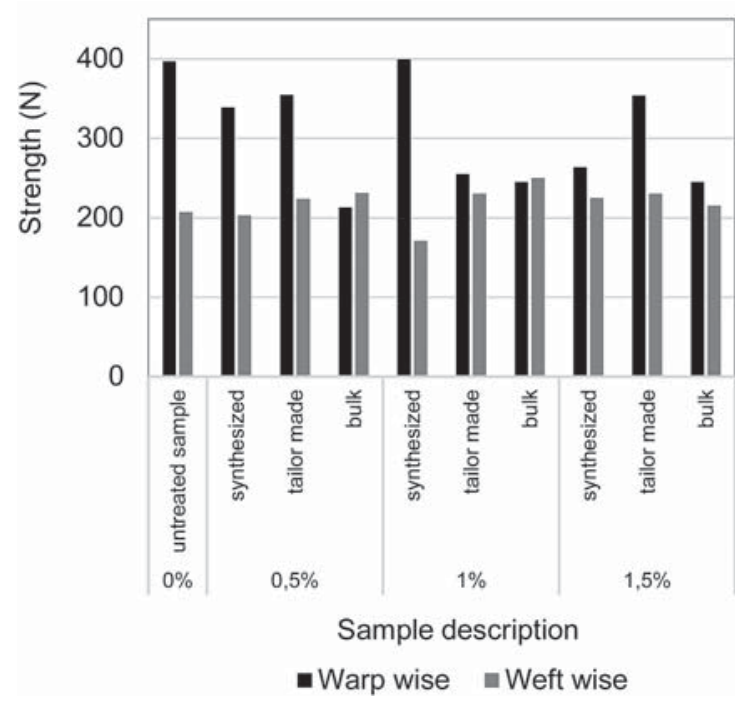

Figure 5: Tensile strength of finished samples

The tensile strength data in Figure 5 ensures that there was a strength loss in the specimen after the finish was applied, while the minimum strength loss was recorded in the case of synthesised nanoparticles with the respective concentration of $1 \%$.

\subsubsection{Stiffness}

The bending length of the nano finished cotton fabric is shown in Figure 6.

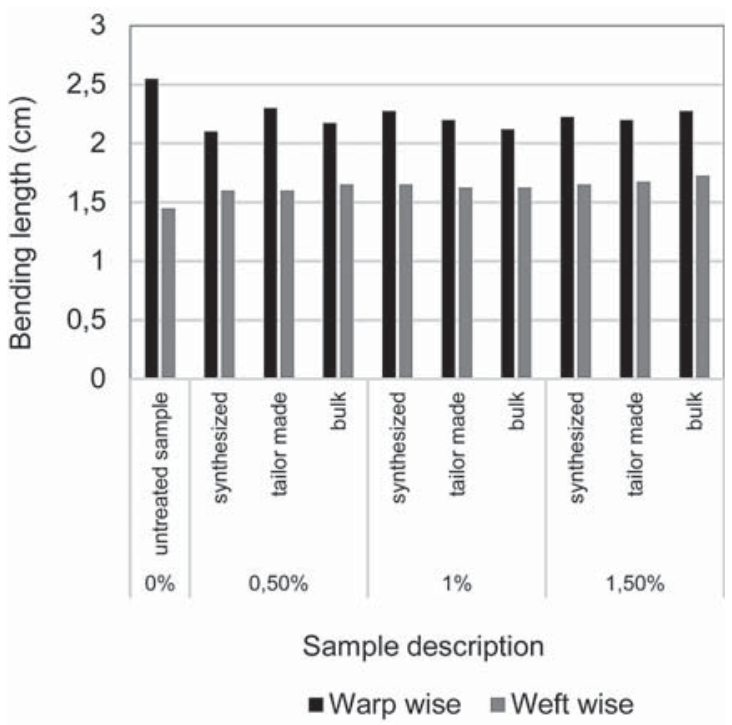

Figure 6: Bending length of finished specimen

It can be concluded that there was no substantial change in the stiffness of finished samples; however, there was a slight change in the stiffness of finished samples as compared to control. The samples were found to become marginally stiffer after the application of the finish. 


\subsubsection{Pore size}

The finished fabric pore size data is given in Figure 7.

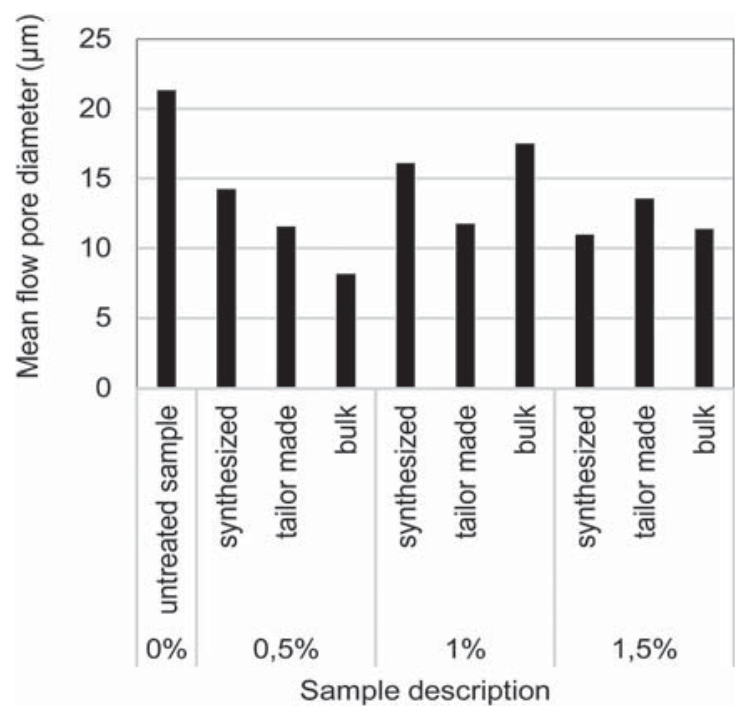

Figure 7: Pore size of different fabric specimen

From the data above, it can be inferred that the application of the nanoparticle finish resulted in a decreased pore size in the fabric substrate. Furthermore, it was observed that the pore size of finished samples was the largest in the case of the tailormade nanoparticle finished fabric.

\section{Conclusion}

Synthesised $\mathrm{SiO}_{2}$ nanoparticles showed enhanced hydrophilic properties and when applied to a fabric, the water absorbency of the fabric increased dramatically. The hydrophilicity was found similar to the tailor-made particle from tailor-made nanoparticles and much better than at bulk silica. Moreover, the synthesis of nanoparticles done at low temperatures facilitated the ease of the nanoparticle synthesis. The application of synthesised $\mathrm{SiO}_{2}$ nanoparticles also improved physical properties such as tensile strength, while bending length (warp and weft wise) did not exhibit any substantial change even after the application of nanoparticles. These properties were found similar (better in some cases) in the case of synthesised nanoparticles with respect to the tailor-made nanoparticles. The performance of bulk particles was lower than at both types of nanoparticles used. These characteristics strongly suggest that the use of silica nanoparticles improves the hydrophilic property of the fabric substrate. These techniques can be easily scaled up to commercial level as well. The enhanced hydrophilic properties may aid the development of better and stronger absorbents for various uses.

\section{References}

1. SAWHNEY, A. P. S., CONDON, Brian Douglas, SINGH, Vikram Kumar, PANG, Su-Seng, LI, Guoqiang, HUI, David. Modern application of nanotechnology in textiles. Textile Research Journal, 2008, 78(8), 731-739, doi: 10.1177/ 0040517508091066.

2. VOLKOV, V. A., SHCHUKINA, E. L., AMARLUI, A., AGEEV, A. A., KUKLEVA, K. K., ELEEV, A. F. Molecular stratification nanotechnology in antiadhesive modification of fabric fibres. Fibre chemistry, 2008, 40(2), 127-135, doi: 10.1007/s10692-008-9024-7.

3. MAZROUEI-SEBDANI, Zahra, KHODDAMI, Akbar. Alkaline hydrolysis: A facile method to manufacture superhydrophobic polyester fabric by fluorocarbon coating. Progress in Organic Coatings, 2011, 72(4), 638-646, doi: 10.1016/j. porgcoat.2011.07.006.

4. SIVAKUMAR, A., MURUGAN, Ramachandran, SUNDARESAN, Krishnakumar, PERIYASAMY, Soodamani. UV protection and selfcleaning finish for cotton fabrics using metal oxide nanoparticles. Indian Journal of Fibre Textile Research, 2013, 38(3), 285-292.

5. KATHIRVELU, S., D'SOUZA, Louis, DHURAI, Bhaarathi. UV protection finishing of textiles using $\mathrm{ZnO}$ nanoparticles. Indian Journal of Fibre Textile Research, 2009, 34(3), 267-273.

6. GUPTA, Deepti, BHAUMIK Somes. Antimicrobial treatments for textiles. Indian Journal of Fibre Textile Research, 2007, 32(2), 254-263.

7. EL-MOLLA, M. M., EL-KHATIB, Eman Mohamed, EL-GAMMAL, Mahmoud, ABDELFATTAH, S. H. Nanotechnology to improve coloration and antimicrobial properties on silk fabrics. Indian Journal of Fibre Textile Research, 2011, 36(3), 266-271.

8. MALAKI, Massoud, HASHEMZADEH, Yasser, TEHRANI, Alireza Fadaei. Abrasion resistance of acrylic polyurethane coatings reinforced by nanosilica. Progress in Organic Coatings, 2018, 125, 507-515, doi: 10.1016/j.porgcoat.2018.07.034.

9. AHMED, Hend Mohamed, ABDELLATIF, Mohamed Mehawed, IBRAHIM, Saber, ABDELLA- 
TIF, Faten Hassan. Mini-emulsified Copolymer/ Silica nanocomposite as effective binder and self-cleaning for textiles coating. Progress in Organic Coatings, 2019, 129, 52-58, doi: 10.1016/j. porgcoat.2019.01.002.

10. ZAHID, Muhammad, HEREDIA-GUERRERO, Jose A., ATHANASSIOU, Athanassia, BAYER, Ilker, S. Robust water repellent treatment for woven cotton fabrics with ecofriendly polymers. Chemical Engineering Journal, 2017, 319, 321-332, doi: 10.1016/j.cej.2017.03.006.

11. ATTIA, Nour, F., MOUSSA, Mona, SHETA, Aida, M. F., TAHA, Rehab, GAMAL, Heba. Synthesis of effective multifunctional textile based on silica nanoparticles. Progress in Organic Coatings, 2017, 106, 41-49, doi: 10.1016/j. porgcoat.2017.02.006.

12. LI, Xiaoyan, LI, Hui, HUANG, Kai, ZOU, Hua, YU, Dengguang, LI, Ying, QIU, Biwei, WANG, Xia. Durable superamphiphobic nano-silica/ epoxy composite coating via coaxial electrospraying method. Applied Surface Science, 2018, 436, 283-292, doi: 10.1016/j.apsusc.2017.11.241.

13. CAI, Ying, LI, Jing, YI, Lingmin, YAN, Xiaojie, LI, Jiawei. Fabricating superhydrophobic and oleophobic surface with silica nanoparticles modified by silanes and environment-friendly fluorinated chemicals. Applied Surface Science, 2018, 450, 102-111, doi: 10.1016/j.apsusc.2018.04.186.

14. FALLAH, Fatemeh, KHORASANI, Manouchehr, EBRAHIMI, Morteza. Improving the mechanical properties of waterborne nitrocellulose coating using nano-silica particles. Progress in Organic Coatings, 2017, 109, 110-116, doi: 10. 1016/j.porgcoat.2017.04.016.

15. ZHOU, Chenglong, XU, Shouping, PI, Pihui, CHENG, Jiang, WANG, Li, YANG, Jinxin, WEN, Xiufang. Polyacrylate/silica nanoparticles hybrid emulsion coating with high silica content for high hardness and dry wear-resistant. Progress in Organic Coatings, 2018, 121, 30-37, doi: 10.1016/j.porgcoat.2018.04.001.

16. SUTHABANDITPONG, W., TAKAI, Chika, FUJI, M., BUNTEM, Radchada, SHIRAI, Takashi. Studies of optical properties of UV-cured acrylate films modified with spherical silica nanoparticles. Advanced Powder Technology, 2016, 27(2), 411-416, doi: 10.1016/j.apt.2016.01.022.

17. ESHAGHI, Akbar. Transparent hard self-cleaning nano-hybrid coating on polymeric substrate. Progress in Organic Coatings, 2019, 128, 120126, doi: 10.1016/j.porgcoat.2018.12.021.
18. LAVERGNE, Francis, BELHADI, R., CARRIAT, J., FRAJ, Amor Ben. Effect of nano-silica particles on the hydration, the rheology and the strength development of a blended cement paste. Cement Concrete Composites, 2019, 95, 42-55, doi: 10.1016/j.cemconcomp.2018.10.007.

19. LIU, Huiting, YU, Yongiin, LIU, Huimin, JIN, Jianzhou, LIU, Shuoqiong. Hybrid effects of nanosilica and graphene oxide on mechanical properties and hydration products of oil well cement. Construction and Building Materials, 2018, 191, 311-319, doi: 10.1016/j.conbuildmat.2018.10.029.

20. WANG, Ren, LIU, Tianle, NING, Fulong, OU, Wenjia, ZHANG, Ling, WANG, Zhen, LI, Peng, SUN, Jiaxin, LIU, Zhichao, LI, Tianshu, SUN, Huicui, JIANG, Guosheng. Effect of hydrophilic silica nanoparticles on hydrate formation: Insight from the experimental study. Journal of Energy Chemistry, 2019, 30, 90-100, doi: 10. 1016/j.jechem.2018.02.021.

21. HSIEH, Chien-Te, CHANG, Bi-Sheng, LIN, JiaYi. Improvement of water and oil repellency on wood substrates by using fluorinated silica nanocoating Applied Surface Science, 2011, 257(18), 7997-8002, doi: 10.1016/j.apsusc.2011.04.071.

22. CHEN, Fang, HABLEEL, Ghanim, ZHAO, Eric Ruike, JOKERST, Jesse V. Multifunctional nanomedicine with silica: role of silica in nanoparticles for theranostic, imaging, and drug monitoring. Journal of Colloid Interface Science, 2018, 521, 261-279, doi: 10.1016/j.jcis.2018.02.053.

23. LEIDNER, Arnold, BAUER, Jens, KHONACHAH, Mojtaba Ebrahimi, TAKAMIYA, Masanari, STRÄHLE, Uwe, DICKMEIS, Thomas, RABE, Kersten S., NIEMEYER, Christof M. Oriented immobilization of a delicate glucose-sensing protein on silica nanoparticles. Biomaterials, 2019, 190-191, 76-85, doi: 10.1016/j.biomaterials. 018. 10.035

24. WANG, Jintao, WANG, Hongfei. Ultra-hydrophobic and mesoporous silica aerogel membranes for efficient separation of surfactant-stabilized water-in-oil emulsion separation. Separation and Purification Technology, 2019, 212, 597-604, doi: 10.1016/j.seppur.2018.11.078.

25. JACOB, Jefferson De Santana, MASCELANI, Amadeu Grezzana, STEINMETZ, Ricardo L. R., DALLA COSTA, Filipe Antonio, DALLA COSTA, Osmar Antonio . Use of silica fume and nano-silica in mortars attacked by acids present in pig manure. Procedia Structural Integrity, 2018, 11, 44-51, doi: 10.1016/j.prostr.2018.11.007. 